Review

\title{
Agri-Food Contexts in Mediterranean Regions: Contributions to Better Resources Management
}

\author{
Vítor João Pereira Domingues Martinho
}

Citation: Martinho, V.J.P.D. Agri-Food Contexts in Mediterranean Regions: Contributions to Better Resources Management. Sustainability 2021, 13, 6683. https://doi.org/ $10.3390 /$ su13126683

Academic Editor: Dalia Štreimikienè

Received: 12 May 2021

Accepted: 10 June 2021

Published: 12 June 2021

Publisher's Note: MDPI stays neutral with regard to jurisdictional claims in published maps and institutional affiliations.

Copyright: (C) 2021 by the author Licensee MDPI, Basel, Switzerland. This article is an open access article distributed under the terms and conditions of the Creative Commons Attribution (CC BY) license (https:// creativecommons.org/licenses/by/ $4.0 /)$.
Agricultural School (ESAV) and CERNAS-IPV Research Centre, Polytechnic Institute of Viseu (IPV), 3504-510 Viseu, Portugal; vdmartinho@esav.ipv.pt

\begin{abstract}
The agri-food frameworks have specific characteristics (production units with small dimensions and in great number with implications in the respective markets) that call for adjusted approaches, even more so when they are considered in Mediterranean contexts (where global warming will have relevant impacts). In fact, the Mediterranean regions and countries have particular specificities (due to their climate conditions) that distinguish them from their neighbours. This is particularly true in Europe, for example, where the southern countries present socioeconomic dynamics (associated with the respective public debt) that are different from those identified in the northern regions. From this perspective, it seems pertinent to analyse the several dimensions of the agri-food systems in the Mediterranean area. To achieve these objectives, a search was carried out on 26 December 2020 on the scientific databases Web of Science Core Collection (WoS) and Scopus for the topics "agr*-food" and "Mediterranean". These keywords were selected after a previous literature survey and to capture the agri-food contexts in Mediterranean regions. The keyword "agr*-food" was considered in this way to allow for a wider search (including "agri-food", "agro-food", etc.). Considering only articles (excluding proceeding papers, book chapters, and books, because in some cases it is difficult to access the entire content of the document), 100 and 117 documents were obtained from the WoS and Scopus, respectively. After removing the duplicated studies and taking into account the PRISMA (Preferred Reporting Items for Systematic Reviews and Meta-Analyses) approach, 137 documents were surveyed through a literature review. As main insights, several dimensions embedded in the concept of agri-food were highlighted, from those related to heritage subjects to natural assets. On the other hand, the following subtopics were identified: agri-food dynamics and sustainability, agriculture and agri-food systems, agri-chains and food consumption, and food production and composition impact on agri-chains. Stressing the gaps in the scientific literature, related to the topics here addressed, there are possibilities to better explore the several dimensions and solutions offered by the new developments associated with smart agriculture and agriculture 4.0, specifically for the Mediterranean contexts and their challenges. Finally, to complement the PRISMA methodologies, an MB2MBA2 (Methodology Based on Benchmarking of Metadata, from scientific databases, and Bibliometric Assessment and Analysis) approach is suggested to carry out systematic literature reviews, based on bibliometric analysis.
\end{abstract}

Keywords: food production; food consumption; agri-chains; sustainability; bibliometric analysis; PRISMA approach

\section{Introduction}

The several dimensions (economic, social, and environmental) of agri-food systems are interrelated with other domains, such as those associated with chains and territory, where, for example, the heritage, socioeconomic dynamics, and natural assets have their importance [1].

On the other hand, agri-food contexts, due to their specificities, are often subject to several public interventions, namely through agricultural policies. This is particularly 
relevant in European Union (EU) countries, due to the different processes of enlargement and the consequent diversity of realities amongst member-states and regions [2].

In association with agricultural policies, institutions appear. Amongst the agri-food organisations, cooperatives appear with a determinant contribution to support in overcoming the particularities of the sector [3]. The cooperatives are crucial to technically support the agri-food stakeholders and help them to concentrate and add value to farm production.

Other approaches to dealing with the characteristics of the sector are the alternative agri-food networks that have appeared over the last decades, across several countries, as an interesting substitute for the traditional normalised systems towards more sustainable and healthy food markets [4].

In addition to its internal particularities, the agri-food sector always deserves special attention because of its environmental externalities and contributions to global warming [5]. In fact, the impacts on the environment from farming activities are having a real influence on the air, soil, and water quality. Achieving a sustainable and healthy agri-food sector seems to be a concern for several stakeholders [6], as well as the interrelationships of this sustainability with rural development [7].

\section{Material and Methods}

Considering the motivations previously described, the main objective of this research is to analyse the several dimensions of the agri-food systems in Mediterranean contexts. For this purpose, 100 and 117 articles (excluding conference papers, book chapters, and books) were obtained from the Web of Science Core Collection [8] and Scopus [9], respectively, in a search carried out on 26 December 2020, without any restriction for the publication year. For this search, the topics "agr*-food" and "Mediterranean" were considered. To allow for a wider search, the "agr*-food" topic was also considered, following Türkeli et al. [10]. This expression allows for the consideration of documents for the several forms considered by the researchers to express the agricultural and food systems, such as agri-food, agro-food, etc. The topic "agr*-food" is represented in this study by the expression agri-food. This expression appears, in general, more frequently than agro-food in WoS and Scopus; nonetheless, specifically for the Mediterranean topic, there are no great differences. These 217 documents were assessed through the PRISMA approach [11], and with the support of the Zotero software [12], the duplicated studies were removed, leaving 137 that were surveyed through literature review. To aid in the organisation of the literature review in subsections, a previous bibliometric analysis was carried out with the VOSviewer software $[13,14]$, considering keywords and terms as items.

The bibliometric analysis is a relevant support to better structure the literature review [15] and provide interesting findings to better understand the scientific trends [16]. In turn, systematic literature reviews are adjusted approaches to assess the state-of-art of the research associated with the topics addressed [17]. In addition, the agri-chains need to deal with new challenges [18] in the coming future [19].

This research follows the approach described before; nonetheless, there are other methodologies followed by other studies, such as, for instance, Sharma et al. [20], that it is important to highlight here. In this study, an MB2MBA2 (Methodology Based on Benchmarking of Metadata, from scientific databases, and Bibliometric Assessment and Analysis) approach with the following phases is suggested (following, for example, Martinho [15] and Kent Baker et al. [21]):

- Selection of the more adjusted scientific databases to work upon, considering the topics to be addressed;

- $\quad$ Removing the duplicated documents and the not relevant ones;

- Assessment of the information obtained from the database(s) selected to identify better methods to be considered in the bibliometric analysis;

- Survey, through a literature review of the total documents or, in case of a great number of studies, the most representative ones as a sample of the total results obtained in the search. 


\section{Bibliometric Analysis}

Figure 1 and Table 1, obtained through the VOSviewer software [14] with bibliographic data, consider co-occurrence as links and keywords as items. In the co-occurrence links, the relatedness of the keywords is based on the number of documents in which they appear together [13]. To obtain this figure and this table, 1 was considered the minimum number of occurrences (number of documents in which a keyword appears) of a keyword [13]. In this figure, the size of each circle associated with each keyword represents the number of occurrences, and the distance between each item (keyword) is related to the level of relatedness.

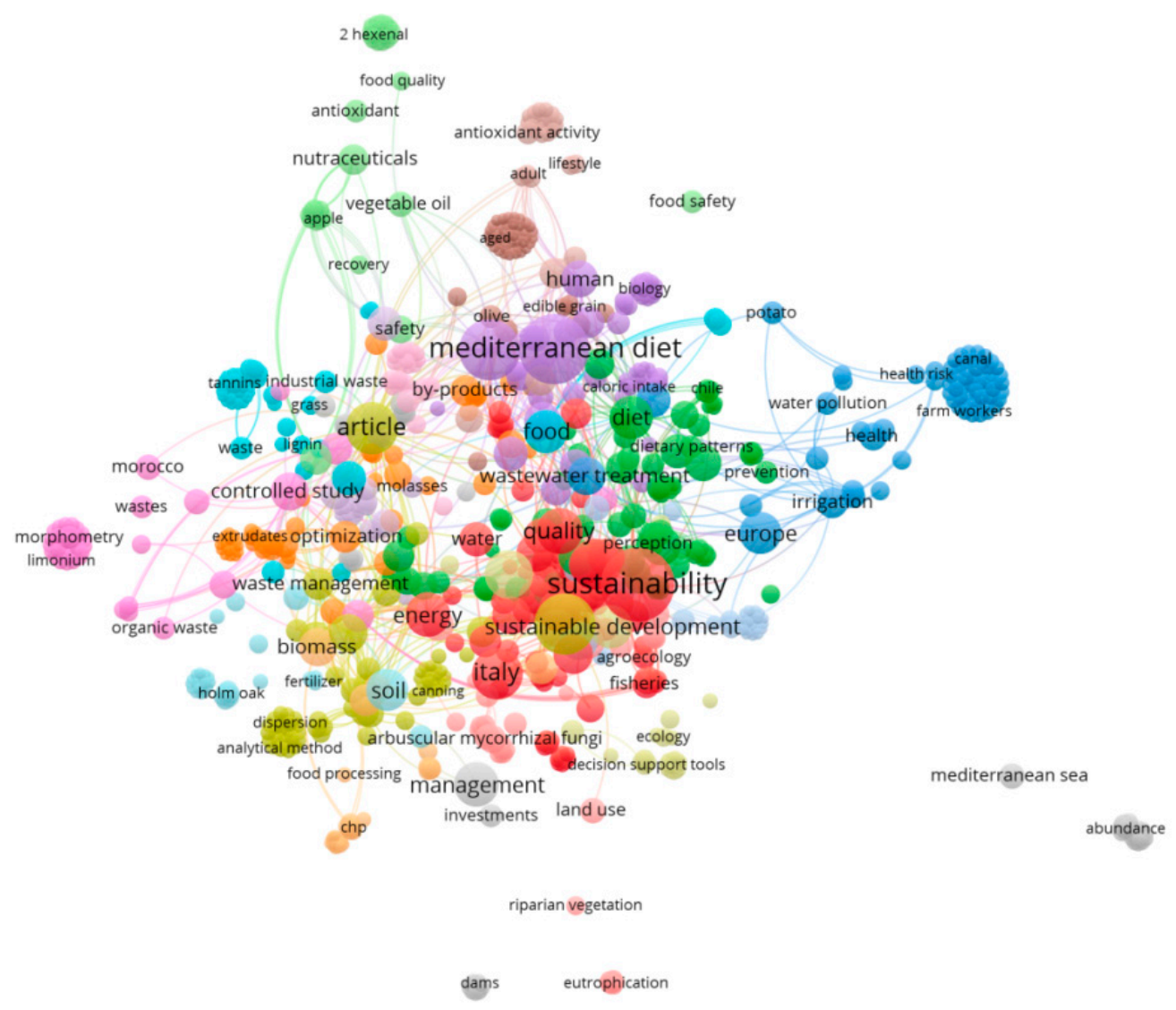

Figure 1. Network visualisation map for bibliographic data, co-occurrence link, and keyword items.

The data presented in Figure 1 and Table 1 highlight the importance of sustainability and agriculture, in their several dimensions, for the agri-food contexts in the Mediterranean regions. On the other hand, the relevance of Europe was shown, namely by Spain and Italy, in the Mediterranean agri-food systems. Specifically, in Table 1, it is possible to identify five great clusters, in terms of diversity of keywords, among the top 50 documents having more occurrences. Cluster 1 displays keywords related to sustainability, where Italy and Spain appear with high occurrences and a recent average publication year, showing that they are current topics. Cluster 2 appears with keywords associated with diet and consumption, Cluster 3 with items such as Europe and waste, Cluster 4 with agriculture, and Cluster 5 with Mediterranean productions, such as olives and fruit. The remaining shorter clusters present keywords that are related to those described for the larger ones. Figure 1 shows all the clusters, and Table 1 shows only those associated with the top50 most relevant items.

Considering text data and terms such as items, Figure 2 and Table 2 were found. In this case, binary counting was considered, and the occurrences represent the number of documents in which a term appears at least once [13]. One was considered the minimum number of occurrences of a term. The size of the circles is related to the number of occurrences and the distance between items is associated with the relatedness. 
Table 1. Top 50 most relevant (more occurrences) keywords for bibliographic data and cooccurrence links.

\begin{tabular}{|c|c|c|c|}
\hline Keywords & Cluster & Occurrences & Avg. Pub. Year \\
\hline sustainability & 1 & 40 & 2017.13 \\
\hline italy & 1 & 19 & 2016.16 \\
\hline spain & 1 & 19 & 2016.95 \\
\hline quality & 1 & 16 & 2017.19 \\
\hline energy & 1 & 15 & 2016.60 \\
\hline trade & 1 & 13 & 2015.15 \\
\hline impacts & 1 & 12 & 2015.83 \\
\hline life cycle assessment & 1 & 11 & 2016.73 \\
\hline performance & 1 & 11 & 2018.09 \\
\hline environmental impact & 1 & 10 & 2014.20 \\
\hline life-cycle assessment & 1 & 10 & 2014.50 \\
\hline lca & 1 & 9 & 2015.78 \\
\hline mediterranean basin & 1 & 9 & 2015.11 \\
\hline water & 1 & 9 & 2017.22 \\
\hline agri-food industry & 1 & 8 & 2016.75 \\
\hline carbon & 1 & 8 & 2013.50 \\
\hline competitiveness & 1 & 8 & 2013.13 \\
\hline environment & 1 & 8 & 2008.75 \\
\hline diet & 2 & 14 & 2018.57 \\
\hline consumption & 2 & 12 & 2018.83 \\
\hline adherence & 2 & 10 & 2019.00 \\
\hline model & 2 & 10 & 2012.90 \\
\hline mediterranean & 2 & 9 & 2006.22 \\
\hline biogas production & 2 & 8 & 2016.75 \\
\hline europe & 3 & 13 & 2012.54 \\
\hline wastewater treatment & 3 & 11 & 2015.82 \\
\hline wastewater & 3 & 9 & 2013.44 \\
\hline agriculture & 4 & 28 & 2015.11 \\
\hline article & 4 & 20 & 2015.85 \\
\hline anaerobic digestion & 4 & 11 & 2017.45 \\
\hline degradation & 4 & 8 & 2017.13 \\
\hline mediterranean diet & 5 & 37 & 2016.62 \\
\hline olive oil & 5 & 28 & 2015.57 \\
\hline human & 5 & 10 & 2016.30 \\
\hline traceability & 5 & 10 & 2018.30 \\
\hline fruits & 5 & 9 & 2017.00 \\
\hline food & 6 & 14 & 2011.71 \\
\hline mediterranean countries & 6 & 9 & 2013.22 \\
\hline controlled study & 9 & 11 & 2017.73 \\
\hline aquaculture & 9 & 8 & 2014.00 \\
\hline impact & 10 & 11 & 2016.82 \\
\hline agri-food trade & 10 & 8 & 2012.13 \\
\hline food waste & 11 & 8 & 2017.88 \\
\hline costs & 12 & 11 & 2015.64 \\
\hline mediterranean region & 13 & 18 & 2010.50 \\
\hline sustainable development & 13 & 14 & 2015.64 \\
\hline polyphenols & 14 & 9 & 2016.44 \\
\hline soil & 15 & 13 & 2015.77 \\
\hline biomass & 16 & 11 & 2015.82 \\
\hline management & 21 & 15 & 2017.20 \\
\hline
\end{tabular}

In this case, Figure 2 and Table 2 also show the importance of sustainability and agriculture in the agri-food systems; nonetheless, they further highlight the relevance of the agri-chains' behaviours, namely in terms of food choice and consumption, food production and composition, and the associated dynamics. After exploring Table 2 in greater depth, it is evident that there are some larger clusters that deserve further analysis. For example, Cluster 3 highlights the importance of food production and agriculture, Cluster 5 shows 
the interrelationships between food production and biodegradability, Cluster 13 shows the role of the University and research for agri-food systems, and Cluster 46 reveals the interrelationships between food production and heritage.

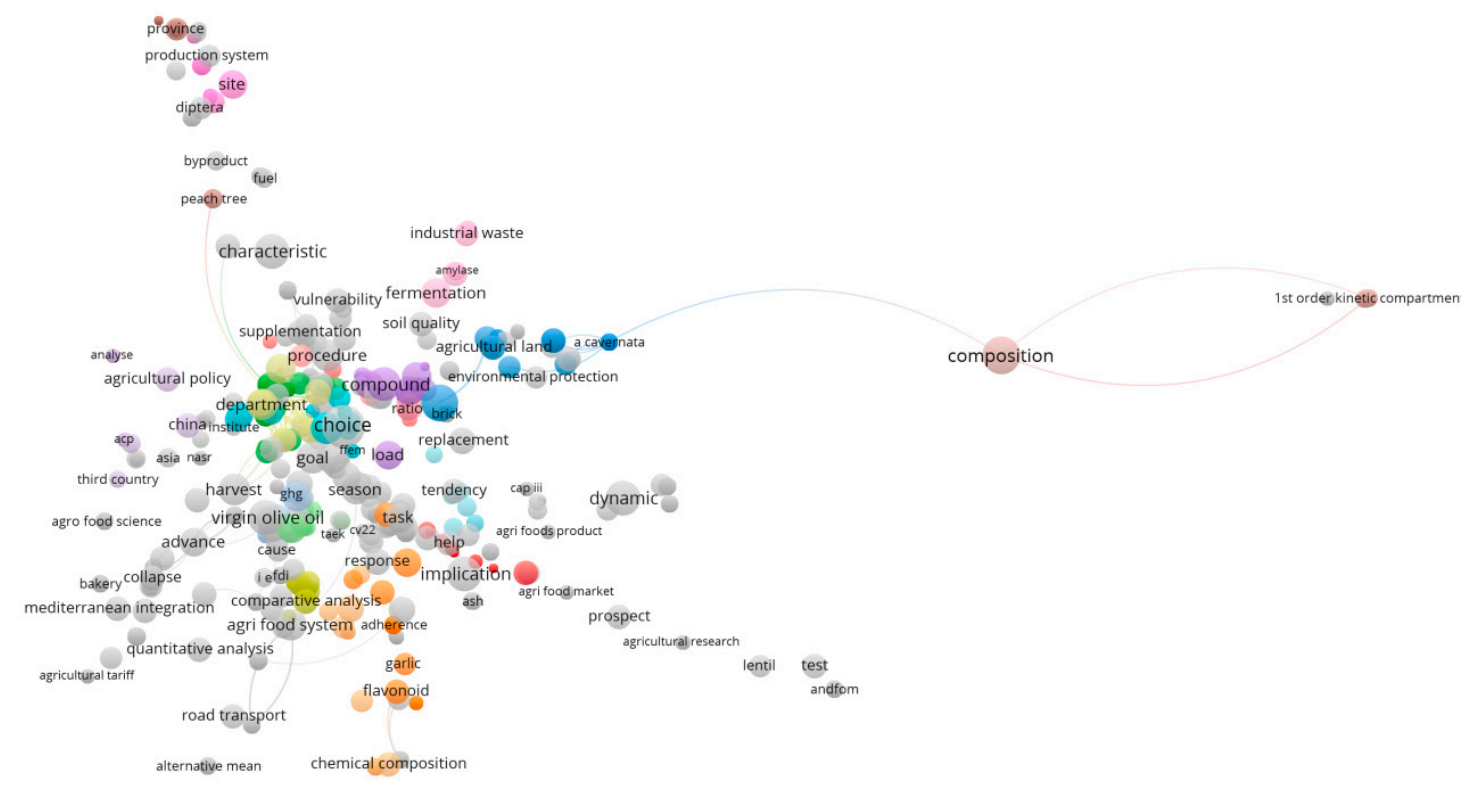

Figure 2. Network visualisation map for text data, co-occurrence links, and terms items.

Table 2. Top 50 most relevant (more occurrences) terms for text data and co-occurrence links.

\begin{tabular}{lccc}
\hline Terms & Cluster & Occurrences & Avg. Pub. Year \\
\hline certification & 1 & 6 & 2018.00 \\
food production & 3 & 13 & 2014.54 \\
agricultural land & 3 & 6 & 2015.50 \\
arbuscular mycorrhizal fungi & 3 & 6 & 2013.50 \\
compound & 5 & 11 & 2015.18 \\
generation & 5 & 9 & 2015.56 \\
amendment & 5 & 8 & 2016.63 \\
load & 5 & 8 & 2016.50 \\
olive pomace & 5 & 8 & 2016.38 \\
anaerobic co digestion & 5 & 6 & 2013.50 \\
biodegradability & 5 & 6 & 2013.50 \\
chloride & 5 & 6 & 2013.50 \\
damage & 6 & 10 & 2011.40 \\
characterisation & 6 & 6 & 2008.50 \\
component & 7 & 8 & 2015.13 \\
site & 9 & 8 & 2014.88 \\
decrease & 10 & 7 & 2019.71 \\
space & 11 & 9 & 2017.56 \\
hotspot & 12 & 9 & 2017.00 \\
department & 13 & 10 & 2014.00 \\
weight & 13 & 9 & 2016.78 \\
agricultural & 13 & 7 & 2015.29 \\
selection & 13 & 7 & 2014.43 \\
university & 13 & 7 & 2015.29 \\
agricultural policy & 14 & 6 & 2017.33 \\
china & 14 & 6 & 2006.50 \\
behaviour & 16 & 7 & 2015.43 \\
chemical composition & 16 & 6 & 2015.00 \\
composition & 17 & 14 & \\
fermentation & 18 & 9 & \\
\hline & & & \\
\hline
\end{tabular}


Table 2. Cont.

\begin{tabular}{lccc}
\hline Terms & Cluster & Occurrences & Avg. Pub. Year \\
\hline replacement & 19 & 7 & 2007.71 \\
choice & 22 & 18 & 2017.61 \\
goal & 23 & 10 & 2018.50 \\
right & 23 & 8 & 2017.13 \\
function & 25 & 7 & 2011.43 \\
dynamic & 26 & 12 & 2013.50 \\
negative effect & 32 & 7 & 2009.29 \\
response & 32 & 7 & 2012.71 \\
question & 37 & 10 & 2015.30 \\
season & 42 & 8 & 2014.25 \\
stage & 43 & 7 & 2015.86 \\
task & 44 & 8 & 2017.88 \\
virgin olive oil & 46 & 12 & 2016.75 \\
advance & 46 & 8 & 2015.50 \\
cultural heritage & 46 & 8 & 2018.88 \\
agri food system & 47 & 10 & 2018.90 \\
procedure & 49 & 10 & 2016.70 \\
implication & 50 & 12 & 2014.50 \\
characteristic & 55 & 12 & 2012.25 \\
harvest & 56 & 10 & 2017.60 \\
\hline
\end{tabular}

Considering the information highlighted here and following, for example, Martinho $[15,22,23]$, who carried out an organised literature review based on previous bibliometric analysis, the literature review will be carried out for the following subtopics: agri-food dynamics and sustainability; agriculture and agri-food systems; agri-chains and food consumption; food production and composition impact on agri-chains.

\section{Systematic Literature Review}

Considering the bibliometric analysis previously performed and a prior general overview of the literature, this section will be organised into the following subsections: agri-food dynamics and sustainability; agriculture and agri-food systems; agri-chains and food consumption; food production and composition impact on agri-chains.

\subsection{Agri-Food Dynamics and Sustainability}

The agri-food sector has relative importance in some European Mediterranean regions, specifically some from Spain [24] and Italy [25]. The by-products of several agri-food activities bring about serious challenges to management [26], more so in some sectors [27], but may provide interesting alternatives for consideration in diverse activities from a sustainable perspective. The use of these by-products as feed for livestock production is an example [28]. The production of bioenergy is another case [29], from the viewpoint of a circular economy [30], where, for instance, the residues from olive oil production have a great potential for bioethanol extraction [31]. This use of the olive oil production residues has environmental advantages compared to the disposal into soil [32], namely, the Olive Mill Wastewaters that pollute the soils [33]. There are also concerns about the agri-food by-product impacts on water [34]. Olive trees and vineyards are amongst the Mediterranean agri-food activities with greater residue production [35]. Other sectors, such as cereals, also have their importance [36]. Other examples, for a sustainable use of the agri-food wastes, may be found in the production of organic fertilisers [37], additives for human eating [38], pharmaceutical products [39], cosmetics [40], polymers [41], animal feed [42], specifically poultry [43], hydrolytic enzymes [44], and bioconversion [45]. Organic fertilisers may be obtained from plant residues, animal waste, and manure [46]. In general, agri-food residues may be considered to replace scarce resources, such as water [47], through wastewater treatments [48], to produce fuels [49] and heat [50] and to obtain 
bioproducts [51]. Sometimes, there are advantages, for the characteristics of the products obtained, to jointly treating different residues through well-designed mixtures [52].

Sustainability has a multidimensional nature [53], and its several dimensions are impacted upon by various factors [54], some of them being difficult to control [55]. The concerns with the agri-food sector in Mediterranean regions [56] and, specifically, regarding sustainability, are old between international institutions [57] and the researchers [58], including in forestry [59]. In this way, for a sustainable development, the mitigation of environmental impacts is a determinant [60] for which bilateral cooperation is sometimes fundamental [61], but the socioeconomic and financial domains also deserve some specific attention. In fact, the financial variables and their relationships with profitability and performance are relevant dimensions to consider and manage in the agri-food sectors [62].

\subsection{Agriculture and Agri-Food Systems}

There are strong relationships between the agricultural sector and the agri-food systems, even a sector upstream of these frameworks, in an interrelationship that involves agriculture, food, and the environment [63]. A sustainable agriculture includes land preservation [64], despite the increased use of agricultural land for non-food production [65]. This alternative use of land may provide an interesting approach to marginal land [66]. In turn, some agricultural crops, such as olive trees, also have a cultural dimension [67]. The agricultural and land policies, including the Common Agricultural Policy [68], have a great impact on these interlinkages [69], as well as agricultural institutions, such as cooperatives [70]. For the design of adjusted agri-food policies, the stakeholders' [71] and policymakers' [72] involvement is fundamental. Agricultural activities are complex systems involving several factors, some of which are biological [73], and others are interrelated with workforce characteristics [74], for example.

The combination of agricultural and forestry activities in a complementary way may bring about interesting contributions, under certain, specific conditions, to the role of the agroforestry sector in agri-food contexts [75]. The Mediterranean area is a global region possessing great biodiversity [76], and there is some call for special attention in order to avoid its extinction [77] and another to bring specificities and potentialities to the agri-food systems [78] in Europe [79]. Some of this biodiversity has spread to other continents [80] and some has come from outside the Mediterranean area [81]. There are great opportunities to improve forest management for a more integrated development, specifically in rural areas [82]. A more integrated rural development is a concern for several countries and institutions around the world [83] that call for innovative approaches, namely where there is an increase in land abandonment [84]. The agricultural sector, in parallel with its contribution towards food security, has social, cultural, and environmental dimensions. Nonetheless, these contributions, in the EU, differ among Central, New Eastern, and Mediterranean countries [85].

Urban agriculture has appeared, supplying new perspectives for the agri-food systems within cities. However, its contribution is not limited to food produced locally. Indeed, urban agriculture also has social and ecological functions [86], in some cases different from those identified for the traditional farming sector. Beyond urban agriculture, local production and consumption is a trend that has grown in the last decades with advantages for the producers, consumers [87], and the whole of society, from the perspective of shorter value chains [88]. Certification is another approach that may support farmers in dealing with the agricultural market's specificities [89]. In any case, certification should be seen as a strategy that must be combined with others, namely those related to sustainability and heritage [90].

\subsection{Agri-Chains and Food Consumption}

The agri-food chains are becoming more competitive around the world, which calls for new firm strategies [91], which are not always socially fair. The agri-chains are complex systems involving several processes and operators. For example, olive oil production 
involves the following phases [92]: olive tree care, fruit harvest, fruit processing, and oil packaging. The supply agri-chains include various steps from cultivation to its end consumption, passing through processing and distribution [93]. The agri-food sector is one of the most important in the world [94]. In agricultural products, the production phase is that which has more environmental impact [95]. This information about the environmental implications associated to each agri-food product should be communicated to consumers in a clear way to better inform their choices [96].

The great concerns in the agri-chains are health and the environment [97], namely the impacts from waste, water, and energy use as well as greenhouse gas emissions [98]. However, in some cases, there is, still, antagonism between indicators related to these two dimensions (health and environment) [99]. The associated policies may bring forth relevant contributions for more balanced agri-chains [100]. Unhealthy food has implications for human welfare [101], especially among children. For these cases, more adjusted agri-food policies are called for [102] as well as innovative solutions that promote healthy food consumption [103]. Another concern is associated with the losses and waste across the food chains [104], including that which is on a nutritional level [105].

The Mediterranean diet (MD), classified as Intangible Cultural Heritage by UNESCO in 2013 [106], is a food label [107]. It is, in general, considered a healthy eating habit that helps to prevent diabetes, cardiovascular diseases, and cancer [108]. Olive oil is one of the most important ingredients of the MD [109], considering its antioxidant properties [110]. The antioxidant properties are also present in other products, such as garlic [111]. However, this healthy diet has changed [112] over recent decades [113], and, in certain circumstances, has been compromised by the pressures from globalisation [114], which promotes the consumption of animal and processed foods [115]. In addition, the MD is more environmentally sustainable [116] and has a cultural dimension [117]. The MD combines tradition, sustainability, and fields of innovation [118] and may be considered a Mediterranean lifestyle (ML) [119].

The agri-chains became, in fact, more globalised over the last few decades, and the successive European Union enlargement contributed further to these processes, with benefits for some sectors and fewer advantages for others [120]. These enlargements increased the diversity of realities inside the EU [121]. In these processes of globalisation, the strategy is to potentiate competitive advantage [122]. In some contexts, this globalisation process is compromised by infrastructural constraints, such as those related to the conditions for transport [123]. Transportation conditions have a relevant influence on the agri-food sector's competitiveness [124]. In any case, the agri-chains are dynamic systems that have changed over the years [125] in adjustment processes towards these new circumstances [126].

There is a historical agri-food trade between the EU Mediterranean countries and their neighbours from North Africa and the Neighbouring East, in the Mediterranean basin [127]. The relative importance of countries outside the EU has increased over the last decades [128]. The Euro-Mediterranean (EUROMED) integration has had its implication in this scenario [129], but the lack of industrial diversification in non-EU Mediterranean countries may be a constraint [130]. The EUROMED partnership has opened up great opportunities, but needs to go ahead [131]. Nonetheless, the trade flow intensities of agri-food products vary in function of the group of countries considered [132], due to their economic and structural specificities [133], special relationships [134], and international frameworks [135]. External shocks, such as the global financial crisis, have impacted the trade pattern between Mediterranean countries [136], as well as, agreements for tariff liberalisation in the region [137]. The chain organisation, transparency and security, infrastructure and conditions of logistics, and transaction costs matter greatly within these frameworks [138].

\subsection{Food Production and Composition Impacts on Agri-Chains}

Processed food production produces several residues that have environmental impacts [139]. The major challenge for the future will be to reduce emissions without com- 
promising the need for food [140]. In addition, food production requires great quantities of resources. One example is the requirement of energy that may be provided by alternatives and renewable sources largely available in Mediterranean countries such as solar resources [141]. Another example is the need for water with its associated costs [142], including those related to dam maintenance and conservation [143]. In these contexts, to reuse and recycle must become the key buzzwords [144], albeit with the correct approach [145], in order to avoid risks to human health [146]. Other buzzwords are agroecology [147], efficiency [148], and optimisation [149] in the use of resources to reduce the costs and the carbon footprint. The agroecology perspective within the agricultural sector may improve the circularity of the agrarian metabolism and reduce the metabolic rift [150]. New technologies [151], including those related to information, technology, and communication [152], and new approaches [153] in the diverse activities [154] may bring direct and indirect additional contributions to agri-food systems and their sustainability [155].

On the other hand, consumers are currently more interested in knowing about the food production processes and the foodstuff's composition [156]. To achieve these consumer preferences, the food industry has searched for alternative products in their processes, such as, for example, hydrosols, which have been used as a natural antimicrobial [157]. In addition, some foodstuffs, due to their composition, are considered functional food or nutraceuticals, due to their pharmacological characteristics [158]. These new tendencies have impacts on agri-food dynamics.

In every sector, including in agri-food contexts with their specificities [159], the cooperation between firms is crucial to better deal with market challenges; however, these alliances are often unstable and asymmetric, more so when they occur among production units of different sizes [160].

\section{Main Insights from the Literature Review and Discussions}

The main insights are presented in Table 3 and reveal the importance of an adjusted management of the by-products as a way to reduce the environmental impacts and find innovative and alternative uses from the perspective of circular economy. Innovative approaches to deal with the increased carbon footprint and that allow improvements in sustainability are determinants for a more balanced development.

Table 3. Public policies and production assets as main axes.

\begin{tabular}{ll}
\hline Documents & Main Insights \\
\hline$[26]$ & $\begin{array}{l}\text { By-products bring about serious challenges to management } \\
\text { Bilateral cooperation is fundamental and may bring relevant contributions for the several dimensions } \\
\text { of the sustainability } \\
\text { [61] }\end{array}$ \\
A sustainable agriculture includes land preservation \\
T64] & The agricultural policies are important drivers of the agri-food contexts \\
{$[69]$} & A more integrated rural development is a concern for several countries and institutions \\
{$[75]$} & The realities, in the EU, differ among Central, New Eastern, and Mediterranean countries \\
{$[83]$} & Urban agriculture also has social and ecological functions \\
{$[85]$} & The agri-food sector is one of the most important worldwide \\
{$[86]$} & There is antagonism between indicators related to the health and environment dimensions \\
{$[94]$} & The Mediterranean diet (MD), classified as Intangible Cultural Heritage by UNESCO in 2013 \\
[99] & There is a historical agri-food trade between the EU Mediterranean countries and their neighbours \\
{$[106]$} & The Euro-Mediterranean (EUROMED) integration has had its implication in the respective countries \\
{$[127]$} & The requirement of energy may be provided by alternatives and renewable sources largely available \\
{$[129]$} & in Mediterranean countries \\
{$[141]$} &
\end{tabular}

In these contexts, the agricultural policies and institutions may bring relevant contributions and play a relevant role, namely to promote interrelationships between the agricultural and forestry sectors in a more integrated rural development. This is a great task considering the diversity of realities in the Mediterranean framework. 
The Mediterranean Diet as food label and lifestyle and Euro-Mediterranean integration are good signs for a deeper cooperation between the Mediterranean countries with advantages for the respective agri-food sectors and contexts.

\section{Conclusions}

The bibliometric analysis, with bibliographic data for the co-occurrence link and keyword items, reveals that, in the top 50 documents with more occurrences, the dimensions related to sustainability and European countries, specifically, Spain and Italy, have their pertinence for the agri-food systems in the Mediterranean area. The same occurs for other dimensions, such as the Mediterranean diet, food waste, Mediterranean production (olive oil, fruits, and wine), agri-chain dynamics, and the interrelationships with heritage. This bibliometric assessment highlights that an analysis of the agri-food frameworks in the Mediterranean region should consider the following groups of dimensions: agri-food dynamics and sustainability, agriculture and agri-food systems, agri-chains and food consumption, and food production and composition impacts on agri-chains.

The literature review was carried out considering these four aggregated dimensions. The interrelationships between the agri-food dynamics and sustainability show the importance of good management of the by-products, specifically to mitigate environmental impacts, reduce the carbon footprint, reduce costs, and find innovative solutions for the agri-food systems in dealing with the changes caused by climate change and global warming. The reuse of water is an interesting example of circular economy that mitigates environmental consequences and allows for the sourcing of an increasingly scarce resource. In the relationships among the agriculture and agri-food systems, the scientific literature highlights the importance of the agricultural sector in agri-chains. The performance of agriculture is conditioned by its particularities, the institutional framework, and the agricultural policies in place. The agricultural policies that impact the farming sector are particularly relevant, namely, in the European Union, in the context of the Common Agricultural Policy. Another aspect is the complementarity between agriculture and other activities, principally forestry, for an integrated rural development and the preservation of biodiversity. Urban agriculture, shorter value chains, and quality certification also appear as crucial fields in the interrelations between agriculture and agri-food systems. Regarding agri-chains and food consumption, the findings reveal that agri-chains are becoming more competitive, where the concerns for environmental and health impacts seem to be increasing; nonetheless, there is a long way to go in what calls for more adjusted policies. The Mediterranean diet/lifestyle appears here as a food label representing healthy eating with a cultural dimension, where globalisation is seen simultaneously as a threat and process with great opportunities to potentiate competitive advantages. These opportunities from international trade could be better promoted in a deeper Euro-Mediterranean (EUROMED) integration, allowing for the increase in commercial exchanges among the European Union and their neighbours from North Africa and the Neighbouring East. Relative to food production and composition impacts on agri-chains, the buzzwords are reuse, recycle, agroecology, efficiency, and optimisation. In addition, modern consumer preferences and interests concerning the composition of foodstuffs condition the food industry to find alternative products for their processes, such as hydrosols, to produce functional food or nutraceuticals.

In terms of practical implications, there are several insights here that may be considered by the several stakeholders (farmers, industrial producers, retailers, and policymakers) to improve agri-food system performance in the Mediterranean region. In theoretical terms, an MB2MBA2 (Methodology Based on Benchmarking of Metadata, from scientific databases, and Bibliometric Assessment and Analysis) approach is suggested to carry out a systematic literature review. On the other hand, a deeper analysis of the new opportunities created by the smart agriculture practices for the Mediterranean frameworks is proposed, as highlighted, for example, by Lezoche et al. [161]. 
For future research and considering the great diversity of realities inside the Mediterranean area, a meta-data analysis by country based on the findings highlighted in this study is suggested. In addition, it is suggested to consider more keywords such as food and agriculture. There are other databases such as Google Scholar, ScienceDirect, Emerald, and Taylor and Francis that may be, also, considered.

Funding: This work is funded by National Funds through the FCT-Foundation for Science and Technology, I.P., within the scope of the project Ref ${ }^{a}$ UIDB/00681/2020.

Institutional Review Board Statement: Not applicable.

Informed Consent Statement: Not applicable.

Data Availability Statement: The data that support the findings of this study are available from the author upon reasonable request.

Acknowledgments: Furthermore, we would like to thank the CERNAS Research Centre and the Polytechnic Institute of Viseu for their support.

Conflicts of Interest: The authors declare no conflict of interest.

\section{References}

1. Arfini, F.; Cozzi, E.; Mancini, M.C.; Ferrer-Perez, H.; Maria Gil, J. Are Geographical Indication Products Fostering Public Goods? Some Evidence from Europe. Sustainability 2019, 11, 272. [CrossRef]

2. Blumberg, R.; Mincyte, D. Beyond Europeanization: The politics of scale and positionality in Lithuania's alternative food networks. Eur. Urban Reg. Stud. 2020, 27, 189-205. [CrossRef]

3. Colom Gorgues, A.; Cos Sanchez, P.; Florensa Guiu, R.M. Agri-food cooperatives in Europe. Dimension, governance and BCG analysis of cooperative societies TOP25 of the EU-28 and TOP10 in Spain. REVESCO Rev. Estud. Coop. 2019, 73-98. [CrossRef]

4. Higgins, V.; Dibden, J.; Cocklin, C. Building alternative agri-food networks: Certification, embeddedness and agri-environmental governance. J. Rural Stud. 2008, 24, 15-27. [CrossRef]

5. Perrot, N.; De Vries, H.; Lutton, E.; van Mil, H.G.J.; Donner, M.; Tonda, A.; Martin, S.; Alvarez, I.; Bourgine, P.; van der Linden, E.; et al. Some remarks on computational approaches towards sustainable complex agri-food systems. Trends Food Sci. Technol. 2016, 48, 88-101. [CrossRef]

6. Ruggeri, A.; Samoggia, A. Twitter communication of agri-food chain actors on palm oil environmental, socio-economic, and health sustainability. J. Consum. Behav. 2018, 17, 75-93. [CrossRef]

7. Sonnino, R. Embeddedness in action: Saffron and the making of the local in southern Tuscany. Agric. Hum. Values 2007, 24, 61-74. [CrossRef]

8. Web of Science Web of Science (Core Collection). Available online: https://apps.webofknowledge.com/WOS_GeneralSearch_ input.do? product=WOS\&search $\_$mode $=$GeneralSearch\&SID $=$F3vCYQ14KvEtaEjWn59\&preferencesSaved $=$(accessed on 26 December 2020).

9. Scopus Scopus Database. Available online: https://www.scopus.com/search/form.uri?display=basic (accessed on 26 December 2020).

10. Türkeli, S.; Kemp, R.; Huang, B.; Bleischwitz, R.; McDowall, W. Circular economy scientific knowledge in the European Union and China: A bibliometric, network and survey analysis (2006-2016). J. Clean. Prod. 2018, 197, 1244-1261. [CrossRef]

11. Liberati, A.; Altman, D.G.; Tetzlaff, J.; Mulrow, C.; Gøtzsche, P.C.; Ioannidis, J.P.A.; Clarke, M.; Devereaux, P.J.; Kleijnen, J.; Moher, D. The PRISMA Statement for Reporting Systematic Reviews and Meta-Analyses of Studies That Evaluate Health Care Interventions: Explanation and Elaboration. PLoS Med. 2009, 6. [CrossRef]

12. Zotero Zotero I Your Personal Research Assistant. Available online: https:/ /www.zotero.org/ (accessed on 26 December 2020).

13. van Eck, N.J.; Waltman, L. VOSviewer Manual; Universiteit Leiden: Leiden, The Netherlands, 2020; p. 53.

14. VOSviewer VOSviewer-Visualizing Scientific Landscapes. Available online: https://www.vosviewer.com/ (accessed on 26 December 2020).

15. Martinho, V.J.P.D. Interrelationships between renewable energy and agricultural economics: An overview. Energy Strategy Rev. 2018, 22, 396-409. [CrossRef]

16. Barbosa, M.W. Uncovering research streams on agri-food supply chain management: A bibliometric study. Global Food Secur. 2021, 28, 100517. [CrossRef]

17. Esposito, B.; Sessa, M.R.; Sica, D.; Malandrino, O. Towards Circular Economy in the Agri-Food Sector. A Systematic Literature Review. Sustainability 2020, 12, 7401. [CrossRef]

18. Ghadge, A.; Kara, M.E.; Mogale, D.G.; Choudhary, S.; Dani, S. Sustainability implementation challenges in food supply chains: A case of UK artisan cheese producers. Prod. Plan. Control. 2020, 1-16. [CrossRef]

19. Mogale, D.G.; Kumar, S.K.; Tiwari, M.K. Green food supply chain design considering risk and post-harvest losses: A case study. Ann Oper Res 2020, 295, 257-284. [CrossRef] 
20. Sharma, R.; Kamble, S.S.; Gunasekaran, A.; Kumar, V.; Kumar, A. A systematic literature review on machine learning applications for sustainable agriculture supply chain performance. Comput. Oper. Res. 2020, 119, 104926. [CrossRef]

21. Kent Baker, H.; Pandey, N.; Kumar, S.; Haldar, A. A bibliometric analysis of board diversity: Current status, development, and future research directions. J. Bus. Res. 2020, 108, 232-246. [CrossRef]

22. Martinho, V.J.P.D. Agricultural Entrepreneurship in the European Union: Contributions for a Sustainable Development. Appl. Sci. 2020, 10, 2080. [CrossRef]

23. Martinho, V.J.P.D. Exploring the Topics of Soil Pollution and Agricultural Economics: Highlighting Good Practices. Agriculture 2020, 10, 24. [CrossRef]

24. Ramon-Muñoz, R. The growth of an agribusiness cluster in Catalonia: Evidence from the olive oil industry. Tijdschr. Soc. Econ. Geschied. 2016, 13, 41-66. [CrossRef]

25. Scarpato, D.; Simeone, M. Euro-Mediterranean integration and competitiveness of the agro-food sector. An empirical analysis in Campania region. New Medit. 2013, 12, 56-63.

26. Serrano, A.; Siles, J.A.; Carmen Gutierrez, M.; Angeles Martin, M. Optimization of Anaerobic Co-digestion of Strawberry and Fish Waste. Appl. Biochem. Biotechnol. 2014, 173, 1391-1404. [CrossRef] [PubMed]

27. Serrano, A.; Siles, J.A.; Chica, A.F.; Angeles Martin, M. Agri-food waste valorization through anaerobic co-digestion: Fish and strawberry residues. J. Clean Prod. 2013, 54, 125-132. [CrossRef]

28. Abbeddou, S.; Riwahi, S.; Iniguez, L.; Zaklouta, M.; Hess, H.D.; Kreuzer, M. Ruminal degradability, digestibility, energy content, and influence on nitrogen turnover of various Mediterranean by-products in fat-tailed Awassi sheep. Anim. Feed Sci. Technol. 2011, 163, 99-110. [CrossRef]

29. Chinnici, G.; Selvaggi, R.; D'Amico, M.; Pecorino, B. Assessment of the potential energy supply and biomethane from the anaerobic digestion of agro-food feedstocks in Sicily. Renew. Sust. Energ. Rev. 2018, 82, 6-13. [CrossRef]

30. Allegra, V.; Bracco, S.; Zarba, A.S. Evolutionary Trends of the Agro-Food Enterprises and Related Atmospheric Emission: The Case of Italy. Qual. Access Success 2018, 19, 13-18.

31. Battista, F.; Mancini, G.; Ruggeri, B.; Fino, D. Selection of the best pretreatment for hydrogen and bioethanol production from olive oil waste products. Renew. Energy 2016, 88, 401-407. [CrossRef]

32. Batuecas, E.; Tommasi, T.; Battista, F.; Negro, V.; Sonetti, G.; Viotti, P.; Fino, D.; Mancini, G. Life Cycle Assessment of waste disposal from olive oil production: Anaerobic digestion and conventional disposal on soil. J. Environ. Manag. 2019, 237, 94-102. [CrossRef]

33. Ramires, F.A.; Durante, M.; Maiorano, G.; Migoni, D.; Rampino, P.; Fanizzi, F.P.; Perrotta, C.; Mita, G.; Grieco, F.; Bleve, G. Industrial scale bio-detoxification of raw olive mill wastewaters by the use of selected microbial yeast and bacterial strains to obtain a new source for fertigation. J. Environ. Manag. 2020, 265. [CrossRef] [PubMed]

34. Sánchez, I.M.R.; Carra, I.; Pérez, J.A.S. Promoting environmental technology using sanitary tax: The case of agro-food industrial wastewater in Spain. Environ. Eng. Manag. J. 2014, 13, 961-969. [CrossRef]

35. Peralbo-Molina, T.; Luque deCastro, M.D. Potential of residues from the Mediterranean agriculture and agrifood industry. Trends Food Sci. Technol. 2013, 32, 16-24. [CrossRef]

36. Selvaggi, R.; Parisi, M.; Pecorino, B. Economic Assessment of Cereal Straw Management in Sicily. Qual. Access Success 2017, 18, 409-415.

37. Antonio Pascual, J.; Belen Morales, A.; Miguel Ayuso, L.; Segura, P.; Ros, M. Characterisation of sludge produced by the agri-food industry and recycling options for its agricultural uses in a typical Mediterranean area, the Segura River basin (Spain). Waste Manag. 2018, 82, 118-128. [CrossRef]

38. Badolati, N.; Masselli, R.; Maisto, M.; Di Minno, A.; Tenore, G.C.; Stornaiuolo, M.; Novellino, E. Genotoxicity Assessment of Three Nutraceuticals Containing Natural Antioxidants Extracted from Agri-Food Waste Biomasses. Foods 2020, 9, 1461. [CrossRef]

39. Cortinhas, A.; Caperta, A.D.; Teixeira, G.; Carvalho, L.; Abreu, M.M. Harnessing sediments of coastal aquaculture ponds through technosols construction for halophyte cultivation using saline water irrigation. J. Environ. Manag. 2020, 261. [CrossRef]

40. Spatafora, C.; Tringali, C. Valorization of vegetable waste: Identification of bioactive compounds and their chemo-enzymatic optimization. Open Agric. J. 2012, 6, 9-16. [CrossRef]

41. Juan Mateo, J.; Maicas, S. Valorization of winery and oil mill wastes by microbial technologies. Food Res. Int. 2015, 73, 13-25. [CrossRef]

42. Monllor, P.; Romero, G.; Muelas, R.; Sandoval-Castro, C.A.; Sendra, E.; Ramon Diaz, J. Ensiling Process in Commercial Bales of Horticultural By-Products from Artichoke and Broccoli. Animals 2020, 10, 831. [CrossRef] [PubMed]

43. Sayehban, P.; Seidavi, A.; Dadashbeiki, M.; Ghorbani, A.; Garcia de Araujo, W.A.; Durazzo, A.; Lucarini, M.; Gabrielli, P.; Omri, B.; Teixeira Albino, L.F.; et al. Olive Pulp and Exogenous Enzymes Feed Supplementation Effect on the Carcass and Offal in Broilers: A Preliminary Study. Agriculture 2020, 10, 359. [CrossRef]

44. Umsza-Guez, M.A.; Diaz, A.B.; de Ory, I.; Blandino, A.; Gomes, E.; Caro, I. Xylanase Production by Aspergillus Awamori Under Solid State Fermentation Conditions on Tomato Pomace. Braz. J. Microbiol. 2011, 42, 1585-1597. [CrossRef]

45. Riudavets, J.; Castane, C.; Agusti, N.; del Arco, L.; Diaz, I.; Castellari, M. Development and Biomass Composition of Ephestia kuehniella (Lepidoptera: Pyralidae), Tenebrio molitor (Coleoptera:Tenebrionidae), and Hermetia illucens (Diptera: Stratiomyidae) Reared on Different Byproducts of the Agri-Food Industry. J. Insect Sci. 2020, 20, 17. [CrossRef] [PubMed] 
46. Thuries, L.; Pansu, M.; Feller, C.; Herrmann, P.; Remy, J.C. Kinetics of added organic matter decomposition in a Mediterranean sandy soil. Soil Biol. Biochem. 2001, 33, 997-1010. [CrossRef]

47. Mekki, H.; Anderson, M.; Amar, E.; Skerratt, G.R.; BenZina, M. Olive oil mill waste water as a replacement for fresh water in the manufacture of fired clay bricks. J. Chem. Technol. Biotechnol. 2006, 81, 1419-1425. [CrossRef]

48. Vergine, P.; Salerno, C.; Libutti, A.; Beneduce, L.; Gatta, G.; Berardi, G.; Pollice, A. Closing the water cycle in the agro-industrial sector by reusing treated wastewater for irrigation. J. Clean Prod. 2017, 164, 587-596. [CrossRef]

49. Manara, P.; Vamvuka, D.; Sfakiotakis, S.; Vanderghem, C.; Richel, A.; Zabaniotou, A. Mediterranean agri-food processing wastes pyrolysis after pre-treatment and recovery of precursor materials: A TGA-based kinetic modeling study. Food Res. Int. 2015, 73, 44-51. [CrossRef]

50. Rovas, D.; Zabaniotou, A. Exergy analysis of a small gasification-ICE integrated system for CHP production fueled with Mediterranean agro-food processing wastes: The SMARt-CHP. Renew. Energy 2015, 83, 510-517. [CrossRef]

51. Kammoun, M.; Ayeb, H.; Bettaieb, T.; Richel, A. Chemical characterisation and technical assessment of agri-food residues, marine matrices, and wild grasses in the South Mediterranean area: A considerable inflow for biorefineries. Waste Manag. 2020, 118, 247-257. [CrossRef]

52. Vico, A.; Pérez-Murcia, M.D.; Bustamante, M.A.; Agulló, E.; Marhuenda-Egea, F.C.; Sáez, J.A.; Paredes, C.; Pérez-Espinosa, A.; Moral, R. Valorization of date palm (Phoenix dactylifera L.) pruning biomass by co-composting with urban and agri-food sludge. J. Environ. Manag. 2018, 226, 408-415. [CrossRef]

53. Casini, M.; Bastianoni, S.; Gagliardi, F.; Gigliotti, M.; Riccaboni, A.; Betti, G. Sustainable Development Goals Indicators: A Methodological Proposal for a Multidimensional Fuzzy Index in the Mediterranean Area. Sustainability 2019, 11, 1198. [CrossRef]

54. Hassanin, A.; Kuwahara, S.; Nurhidayat; Tsukamoto, Y.; Ogawa, K.; Hiramatsu, K.; Sasaki, F. Functional changes of the LHimmunoreactive cells in adenohypophysis of the common carp (Cyprinus carpio) from rivers contaminated with estrogenic chemicals. J. Vet. Med. Sci. 2003, 65, 485-490. [CrossRef]

55. Diaz, J.; Linares, C.; Carmona, R.; Russo, A.; Ortiz, C.; Salvador, P.; Trigo, R.M. Saharan dust intrusions in Spain: Health impacts and associated synoptic conditions. Environ. Res. 2017, 156, 455-467. [CrossRef]

56. Rastoin, J. World Strategy Employed by Agri-Food Multi-Nationals in Euro-Mediterranean Area. World Agric. 1977, $26,18-21$.

57. European Community Commission. Agricultural research: Progress and prospects. In Green Europe: Newsletter, Common Agricultural Policy; European Community Commission: Brussels, Belgium, 1984; p. 27.

58. Agro-food prospects. In Futures for the Mediterranean Basin; Oxford University Press: Oxford, UK, 1989 ; pp. 81-102.

59. The protective forest. In Futures for the Mediterranean Basin; Oxford University Press: Oxford, UK, 1989 ; pp. $206-213$.

60. Coley, D.; Howard, M.; Winter, M. Food miles: Time for a re-think? Br. Food J. 2011, 113, 919-934. [CrossRef]

61. Sánchez, M.A.A. Towards a Spanish-Moroccan cooperation in environmental issues: The implementation of the European Maritime Strategy in the city of Melilla. Rev. Estud. Reg. 2014, 17-42.

62. Alarcón, S. The trade credit in the Spanish agro-food industry. New Medit. 2011, 10, 51-57.

63. Shahbazi, F.; Jafarzadeh, A.A. Integrated assessment of rural lands for sustainable development using MicroLEIS DSS in West Azerbaijan, Iran. Geoderma 2010, 157, 175-184. [CrossRef]

64. Vastola, A.; Zdruli, P.; D’Amico, M.; Pappalardo, G.; Viccaro, M.; Di Napoli, F.; Cozzi, M.; Romano, S. A comparative multidimensional evaluation of conservation agriculture systems: A case study from a Mediterranean area of Southern Italy. Land Use Pol. 2017, 68, 326-333. [CrossRef]

65. Pellegrino, E.; Di Bene, C.; Tozzini, C.; Bonari, E. Impact on soil quality of a 10-year-old short-rotation coppice poplar stand compared with intensive agricultural and uncultivated systems in a Mediterranean area. Agric. Ecosyst. Environ. 2011, 140, 245-254. [CrossRef]

66. Sanchez, J.; Dolores Curt, M.; Fernandez, J. Approach to the potential production of giant reed in surplus saline lands of Spain. GCB Bioenergy 2017, 9, 105-118. [CrossRef]

67. Russo, G.; Beritognolo, I.; Bufacchi, M.; Stanzione, V.; Pisanelli, A.; Ciolfi, M.; Lauteri, M.; Brush, S.B. Advances in biocultural geography of olive tree (Olea europaea L.) landscapes by merging biological and historical assays. Sci. Rep. 2020, 10. [CrossRef] [PubMed]

68. Serrano, A.; Valbuena, J. The effect of decoupling on water resources: Insights from European international trade. J. Environ. Manag. 2020. [CrossRef]

69. Baysse-Laine, A.; Perrin, C. How can alternative farmland management styles favour local food supply? A case study in the Larzac (France). Land Use Policy 2018, 75, 746-756. [CrossRef]

70. Campos-Climent, V.; Apetrei, A.; Chaves-Avila, R. Delphi method applied to horticultural cooperatives. Manag. Decis. 2012, 50, 1266-1284. [CrossRef]

71. Dubeuf, J.-P.; Ruiz Morales, F.D.A.; Guerrero, Y.M. Evolution of goat production systems in the Mediterranean basin: Between ecological intensification and ecologically intensive production systems. Small Ruminant Res. 2018, 163, 2-9. [CrossRef]

72. El Chami, D.; El Moujabber, M. Competitiveness of Lebanese wine: New shoots from ancient roots. J. Wine Res. 2014, $25,298-311$. [CrossRef]

73. Turrini, A.; Sbrana, C.; Avio, L.; Njeru, E.M.; Bocci, G.; Barberi, P.; Giovannetti, M. Changes in the composition of native root arbuscular mycorrhizal fungal communities during a short-term cover crop-maize succession. Biol. Fertil. Soils 2016, 52, 643-653. [CrossRef] 
74. Zimmerer, K.S.; Jiménez-Olivencia, Y.; Ruiz-Ruiz, A.; Porcel-Rodríguez, L. Agri-food land transformations and immigrant farm workers in Peri-urban areas of spain and the mediterranean. Land 2020, 9, 472. [CrossRef]

75. Panozzo, A.; Huang, H.; Bernazeau, B.; Vamerali, T.; Samson, M.F.; Desclaux, D. Morphology, Phenology, Yield, and Quality of Durum Wheat Cultivated within Organic Olive Orchards of the Mediterranean Area. Agronomy 2020, 10, 1789. [CrossRef]

76. Bromfield, E.S.P.; Cloutier, S.; Robidas, C.; Tran Thi, T.V.; Darbyshire, S.J. Invasive Galega officinalis (Goat's rue) plants in Canada form a symbiotic association with strains of Neorhizobium galegae sv. officinalis originating from the Old World. Ecol. Evol. 2019, 9, 6999-7004. [CrossRef] [PubMed]

77. Cañadas, A.; Vázquez, J.A. Conserving Cuvier's beaked whales in the Alboran Sea (SW Mediterranean): Identification of high density areas to be avoided by intense man-made sound. Biol. Conserv. 2014, 178, 155-162. [CrossRef]

78. Corrado, G.; Imperato, A.; La Mura, M.; Perri, E.; Rao, R. Genetic diversity among olive varieties of Southern Italy and the traceability of olive oil using SSR markers. J. Horticult. Sci. Biotechnol. 2011, 86, 461-466. [CrossRef]

79. Marra, F.P.; Lo Bianco, R.; La Mantia, M.; Caruso, T. Growth, yield and fruit quality of "Tropic Snow" peach on size-controlling rootstocks under dry Mediterranean climates. Sci. Hortic. 2013, 160, 274-282. [CrossRef]

80. Lamb, R.J.; Smith, M.A.H.; Wise, I.L.; McKenzie, R.I.H. Resistance to wheat midge (Diptera: Cecidomyiidae) in winter wheat and the origins of resistance in spring wheat (Poaceae). Can. Entomol. 2015, 148, 229-238. [CrossRef]

81. Martínez-Calvo, J.; Badenes, M.L.; Llácer, G.; Bleiholder, H.; Hack, H.; Meier, U. Phenological growth stages of loquat tree (Eriobotrya japonica (Thunb.) Lindl.). Ann. App. Biol. 1999, 134, 353-357. [CrossRef]

82. Besacier, C.; Gallo Granizo, C. Exploring REDD+ opportunities in the Mediterranean-A regional project funded by the French Global Environment Facility (FFEM). Unasylva 2014, 65, 56-59.

83. Bezhani, E. The result and the impact of project IPARD for the rural and agricultural development. Mediterranean J. Soc. Sci. 2015, 6, 602-604. [CrossRef]

84. Filippini, R.; Gennai-Schott, S.; Sabbatini, T.; Lardon, S.; Marraccini, E. Quality Labels as Drivers of Peri-Urban Livestock Systems Resilience. Land 2020, 9, 211. [CrossRef]

85. Dos Santos, M.J.P.L.; Ahmad, N. Sustainability of European agricultural holdings. J. Saudi Soc. Agric. Sci. 2020, 19, 358-364. [CrossRef]

86. Donadieu, P. Building Urban Agricultural Commons: A Utopia or a Reality? Chall. Sustain. 2016, 4, 3-9. [CrossRef]

87. Inacio dos Santos, A.C.; Lessa, J. Communication Design and Municipal Markets Recognition in the Mediterranean Context. Rosa Ventos 2017, 9, 488-504. [CrossRef]

88. Lara, L.G.; Pereira, L.M.; Ravera, F.; Jimenez-Aceituno, A. Flipping the Tortilla: Social-Ecological Innovations and Traditional Ecological Knowledge for More Sustainable Agri-Food Systems in Spain. Sustainability 2019, 11, 1222. [CrossRef]

89. Mattas, K.; Baourakis, G.; Tsakiridou, E.; Hedoui, M.A.; Hosni, H. PDO Olive Oil Products: A Powerful Tool for Farmers and Rural Areas. J. Int. Food Agribus. Mark. 2020, 32, 313-336. [CrossRef]

90. Sanz Canada, J.; Macias Vazquez, A. Protected designations of origin and innovations: The olive oil branch in Sierra Magina (Andalusia). Cah. Agric. 2008, 17, 542-546. [CrossRef]

91. de Castro, C.; Reigada, A.; Gadea, E. The devaluation of female labour in fruit and vegetable packaging plants in Spanish Mediterranean agriculture. Organization 2020, 27, 232-250. [CrossRef]

92. Gonzalez-Fernandez, I.; Iglesias-Otero, M.A.; Esteki, M.; Moldes, O.A.; Mejuto, J.C.; Simal-Gandara, J. A critical review on the use of artificial neural networks in olive oil production, characterization and authentication. Crit. Rev. Food Sci. Nutr. 2019, 59, 1913-1926. [CrossRef]

93. Ingrao, C.; Faccilongo, N.; Valenti, F.; De Pascale, G.; Di Gioia, L.; Messineo, A.; Arcidiacono, C. Tomato puree in the Mediterranean region: An environmental Life Cycle Assessment, based upon data surveyed at the supply chain level. J. Clean Prod. 2019, 233, 292-313. [CrossRef]

94. Scuderi, A.; Foti, V.; Timpanaro, G. The Supply Chain Value of Pod and Pgi Food Products through the Application of Blockchain. Qual. Access Success 2019, 20, 580-587.

95. Lo Giudice, A.; Mbohwa, C.; Clasadonte, M.T.; Ingrao, C. Environmental assessment of the citrus fruit production in sicily using lca. Ital. J. Food Sci. 2013, 25, 202-212.

96. Pattara, C.; Russo, C.; Antrodicchia, V.; Cichelli, A. Carbon footprint as an instrument for enhancing food quality: Overview of the wine, olive oil and cereals sectors. J. Sci. Food Agric. 2017, 97, 396-410. [CrossRef] [PubMed]

97. Moresi, M.; Valentini, R. Food choices adhering to the mediterranean diet to limit the environmental impact of the Italian agro-food sector. Ind. Aliment. 2010, 49, 9-20.

98. Moresi, M. Assessment of the life cycle greenhouse gas emissions in the food industry. Agro Food Ind. Hi-Tech 2014, 25, 53-62.

99. Seconda, L.; Baudry, J.; Alles, B.; Soler, L.-G.; Hercberg, S.; Langevin, B.; Pointereau, P.; Lairon, D.; Kesse-Guyot, E. Identification of sustainable dietary patterns by a multicriteria approach in the NutriNet-Sante cohort. J. Clean Prod. 2018, 196, $1256-1265$. [CrossRef]

100. Verger, E.O.; Perignon, M.; El Ati, J.; Darmon, N.; Dop, M.-C.; Drogue, S.; Dury, S.; Gaillard, C.; Sinfort, C.; Amiot, M.-J.; et al. A "Fork-to-Farm" Multi-Scale Approach to Promote Sustainable Food Systems for Nutrition and Health: A Perspective for the Mediterranean Region. Front. Nutr. 2018, 5, 30. [CrossRef] [PubMed]

101. Duru, M. Trends in agri-food choices for health since the 1960s: The case of fatty acids. OCL Oilseeds Fats Crops Lipids 2019, $26,44$. [CrossRef] 
102. Angel Royo-Bordonada, M.; Rodriguez-Artalejo, F.; Bes-Rastrollo, M.; Fernandez-Escobar, C.; Gonzalez, C.A.; Rivas, F.; Angel Martinez-Gonzalez, M.; Quiles, J.; Bueno-Cavanillas, A.; Navarrete-Munoz, E.M.; et al. Food policies to prevent obesity and the main non-transmissible diseases in Spain: Where there's a will there's a way. Gac. Sanit. 2019, 33, 584-592. [CrossRef]

103. Formoso, G.; Pipino, C.; Antonia Baldassarre, M.P.; Del Boccio, P.; Zucchelli, M.; D’Alessandro, N.; Tonucci, L.; Cichelli, A.; Pandolfi, A.; Di Pietro, N. An Italian innovative small-scale approach to promote the conscious consumption of healthy food. Appl. Sci. 2020, 10, 5678. [CrossRef]

104. Fernandez-Zamudio, M.-A.; Barco, H.; Schneider, F. Direct measurement of mass and economic harvest and post-harvest losses in spanish persimmon primary production. Agriculture 2020, 10, 581. [CrossRef]

105. Garcia-Herrero, I.; Margallo, M.; Laso, J.; Batlle-Bayer, L.; Bala, A.; Fullana-i-Palmer, P.; Vazquez-Rowe, I.; Gonzalez, M.J.; Amo-Setien, F.; Dura, M.J.; et al. Nutritional data management of food losses and waste under a life cycle approach: Case study of the Spanish agri-food system. J. Food Compos. Anal. 2019, 82, 103223. [CrossRef]

106. Pias, F. Design Contributions to Adopt Mediterranean Diet. Case Study Oranges from Silves. J. Spat. Organ. Dyn. 2018, 6, 174-181.

107. Marques da Silva, A.J. From the Mediterranean Diet to the Diaita: The Epistemic Making of a Food Label. Int. J. Cult. Prop. 2018, 25, 573-595. [CrossRef]

108. Azzini, E.; Maiani, G.; Turrini, A.; Intorre, F.; Lo Feudo, G.; Capone, R.; Bottalico, F.; El Bilali, H.; Polito, A. The healthnutrition dimension: A methodological approach to assess the nutritional sustainability of typical agro-food products and the Mediterranean diet. J. Sci. Food Agric. 2018, 98, 3684-3705. [CrossRef]

109. Kalaitzis, P.; El-Zein, Z. Olive oil authentication, traceability and adulteration detection using DNA-based approaches. Lipid Technol. 2016, 28, 173-176. [CrossRef]

110. Pounis, G.; Di Castelnuovo, A.; Bonaccio, M.; Costanzo, S.; Persichillo, M.; Krogh, V.; Donati, M.B.; de Gaetano, G.; Iacoviello, L. Flavonoid and lignan intake in a Mediterranean population: Proposal for a holistic approach in polyphenol dietary analysis, the Moli-sani Study. Eur. J. Clin. Nutr. 2016, 70, 338-345. [CrossRef] [PubMed]

111. Vadala, R.; Mottese, A.F.; Bua, G.D.; Salvo, A.; Mallamace, D.; Corsaro, C.; Vasi, S.; Giofre, S.V.; Alfa, M.; Cicero, N.; et al. Statistical Analysis of Mineral Concentration for the Geographic Identification of Garlic Samples from Sicily (Italy), Tunisia and Spain. Foods 2016, 5, 20. [CrossRef] [PubMed]

112. Lepellere, M.A.; Chang, T.F.M.; Droli, M.; Iseppi, L. The hidden turning points of the Mediterranean diet: A tool for health and agro-food policies. Rating out of fifty years, and 22 countries. New Medit. 2019, 18, 71-88. [CrossRef]

113. Varela-Moreiras, G.; Ruiz, E.; Valero, T.; Manuel Avila, J.; del Pozo, S. The Spanish diet: An update. Nutr. Hosp. $2013,28,13-20$.

114. Bertuccioli, A.; Ninfali, P. The Mediterranean Diet in the era of globalization: The need to support knowledge of healthy dietary factors in the new socio-economical framework. Mediterr. J. Nutr. Metab. 2014, 7, 75-86. [CrossRef]

115. Blanco-Gutierrez, I.; Varela-Ortega, C.; Manners, R. Evaluating Animal-Based Foods and Plant-Based Alternatives Using Multi-Criteria and SWOT Analyses. Int. J. Environ. Res. Public Health 2020, 17, 7969. [CrossRef] [PubMed]

116. Germani, A.; Vitiello, V.; Giusti, A.M.; Pinto, A.; Donini, L.M.; del Balzo, V. Environmental and economic sustainability of the Mediterranean Diet. Int. J. Food Sci. Nutr. 2014, 65, 1008-1012. [CrossRef]

117. Blas, A.; Garrido, A.; Unver, O.; Willaarts, B. A comparison of the Mediterranean diet and current food consumption patterns in Spain from a nutritional and water perspective. Sci. Total Environ. 2019, 664, 1020-1029. [CrossRef] [PubMed]

118. Capone, R.; El Bilali, H.; Bottalico, F. Assessing the Sustainability of Typical Agro-Food Products: Insights from Apulia Region, Italy. New Medit 2016, 15, 28-35.

119. Echeverria, G.; Tiboni, O.; Berkowitz, L.; Pinto, V.; Samith, B.; von Schultzendorff, A.; Pedrals, N.; Bitran, M.; Ruini, C.; Ryff, C.D.; et al. Mediterranean Lifestyle to Promote Physical, Mental, and Environmental Health: The Case of Chile. Int. J. Environ. Res. Public Health 2020, 17, 8482. [CrossRef]

120. Bojnec, S.; Ferto, I. European Enlargement and Agro-Food Trade. Can. J. Agric. Econ. Rev. Can. Agroecon. 2008, 56, 563-579. [CrossRef]

121. Chang, T.F.M.; Iseppi, L. Specialization Versus Diversification in EU Economies: A Challenge for Agro-Food? Transit. Stud. Rev. 2011, 18, 16-37. [CrossRef]

122. Ubrežiová, I.; Kapsdorferová, Z.; Sedliaková, I. Competitiveness of Slovak agri-food commodities in third country markets. Acta Univ. Agric. Silvic. Mendel. Brun. 2012, 60, 379-386. [CrossRef]

123. Carlos Perez-Mesa, J.; Carmen Garcia-Barranco, M.; Piedra-Munoz, L.; Galdeano-Gomez, E. Transport as a limiting factor for the growth of Spanish agri-food exports. Res. Transp. Econ. 2019, 78, 100756. [CrossRef]

124. Schimmenti, E.; Galati, A.; Carapezza, R. Sicilian floriculture companies and the rote of transport in increasing their competitiveness. New Medit 2008, 7, 20-28.

125. Longo, S.B. Mediterranean Rift: Socio-Ecological Transformations in the Sicilian Bluefin Tuna Fishery. Crit. Sociol. 2012, 38, 417-436. [CrossRef]

126. Longo, S.B.; Clark, B. The Commodification of Bluefin Tuna: The Historical Transformation of the Mediterranean Fishery. J. Agrar. Chang. 2012, 12, 204-226. [CrossRef]

127. Crescimanno, M.; Farruggia, D.; Galati, A.; Siggia, D. The intensity of agri-food trade between the countries of the Mediterranean basin. Econ. Agro Aliment 2013, 15, 13-35. [CrossRef]

128. Pappalardo, G.; Allegra, V.; Bucca, M.; Zarbà, A.S. Euro-Mediterranean agri-food trade. Contribution to the development of the "Barcelona Process: The Union for the Mediterranean.". Econ. Agro Aliment. 2013, 15, 37-72. [CrossRef] 
129. Scarpato, D.; Simeone, M.; Rotondo, G. The challenge of Euro-Mediterranean integration for Campania agribusiness sustainability. Agric. Econ. 2019, 65, 539-549. [CrossRef]

130. Tovias, A.; Bacaria, J. Free trade and the Mediterranean. Mediterr. Polit. 1999, 4, 3-22. [CrossRef]

131. Zaim, F. The third generation of Euro-Mediterranean association agreements: A view from the south. Mediterr. Polit. 1999, 4, 36-52. [CrossRef]

132. Crescimanno, M.; Galati, A.; Siggia, D.; Farruggia, D. Intensity of Italy's agri-food trade with countries outside the EU Mediterranean. Int. J. Bus. Glob. 2013, 10, 31-38. [CrossRef]

133. Crescimanno, M.; Galati, A.; Yahiaoui, D. Determinants of Italian agri-food exports in non-EU Mediterranean Partner Countries: An empirical investigation through a gravity model approach. New Medit. 2013, 12, 46-54.

134. Mulazzani, L.; Malorgio, G. Market dynamics and commercial flows in the Mediterranean area: Triangular effects among the EU, the MPCs and Italy in the fruit and vegetable sector. New Medit. 2009, 8, 37-45.

135. Crescimanno, M.; Galati, A.; Bal, T. The role of the economic crisis on the competitiveness of the agri-food sector in the main Mediterranean countries. Agric. Econ. 2014, 60, 49-64. [CrossRef]

136. Rondinella, S.; Agostino, M.; Demaria, F.; Drogué, S. Similarity and Competition in the Agri-Food Trade among European Mediterranean Countries. Int. Trade J. 2019, 33, 444-468. [CrossRef]

137. Tudela-Marco, L.; Garcia-Alvarez-Coque, J.-M.; Martinez-Gomez, V. Are non-tariff measures a substitute for tariffs in agricultural trade? Recent evidence from southern Mediterranean countries. Outlook Agric. 2014, 43, 235-240. [CrossRef]

138. Mili, S. Value chain dynamics of agri-food exports from southern mediterranean to the European union: End-market perspective. Intl. J. Food Syst. 2016, 7, 311-327. [CrossRef]

139. Cappelletti, G.M.; Nicolettp, G.M.; Russo, C. Life Cycle Assessment (LCA) of Spanish-style green table olives. Ital. J. Food Sci. 2010, 22, 3-14.

140. Desmit, X.; Thieu, V.; Billen, G.; Campuzano, F.; Duliere, V.; Garnier, J.; Lassaletta, L.; Menesguen, A.; Neves, R.; Pinto, L.; et al. Reducing marine eutrophication may require a paradigmatic change. Sci. Total Environ. 2018, 635, 1444-1466. [CrossRef]

141. Buscemi, A.; Panno, D.; Ciulla, G.; Beccali, M.; Lo Brano, V. Concrete thermal energy storage for linear Fresnel collectors: Exploiting the South Mediterranean's solar potential for agri-food processes. Energy Conv. Manag. 2018, 166, 719-734. [CrossRef]

142. Ruperez-Moreno, C.; Senent-Aparicio, J.; Martinez-Vicente, D.; Luis Garcia-Arostegui, J.; Cabezas Calvo-Rubio, F.; Perez-Sanchez, J. Sustainability of irrigated agriculture with overexploited aquifers: The case of Segura basin (SE, Spain). Agric. Water Manag. 2017, 182, 67-76. [CrossRef]

143. López, J.P.; De Cea Azañedo, J.C.; García, E.E. The maintenance and conservation of Spanish dams: Prioritizing investments is necessary. Rev. Obras. Publicas. 2014, 161, 21-30.

144. Dutournie, P.; Jeguirim, M.; Khiari, B.; Goddard, M.-L.; Jellali, S. Olive Mill Wastewater: From a Pollutant to Green Fuels, Agricultural Water Source, and Bio-Fertilizer. Part 2: Water Recovery. Water 2019, 11, 768. [CrossRef]

145. Sousa, D.; Venancio, A.; Belo, I.; Salgado, J.M. Mediterranean agro-industrial wastes as valuable substrates for lignocellulolytic enzymes and protein production by solid-state fermentation. J. Sci. Food Agric. 2018, 98, 5248-5256. [CrossRef] [PubMed]

146. Forslund, A.; Ensink, J.H.J.; Battilani, A.; Kljujev, I.; Gola, S.; Raicevic, V.; Jovanovic, Z.; Stikic, R.; Sandei, L.; Fletcher, T.; et al. Faecal contamination and hygiene aspect associated with the use of treated wastewater and canal water for irrigation of potatoes (Solanum tuberosum). Agric. Water Manag. 2010, 98, 440-450. [CrossRef]

147. Migliorini, P.; Gkisakis, V.; Gonzalvez, V.; Dolores Raigon, M.; Barberi, P. Agroecology in Mediterranean Europe: Genesis, State and Perspectives. Sustainability 2018, 10, 2724. [CrossRef]

148. Greco, C.; Campiotti, A.; de Rossi, P.; Febo, P.; Giagnacovo, G. Energy consumption and improvement of energy efficiency for the European agricultural-food system. Riv. Studi Sulla Sostenibilita 2020, 2020, 92-103. [CrossRef]

149. Ramos-Teodoro, J.; Gimenez-Miralles, A.; Rodriguez, F.; Berenguel, M. A Flexible Tool for Modeling and Optimal Dispatch of Resources in Agri-Energy Hubs. Sustainability 2020, 12, 8820. [CrossRef]

150. Padro, R.; Tello, E.; Marco, I.; Olarieta, J.R.; Grasa, M.M.; Font, C. Modelling the scaling up of sustainable farming into Agroecology Territories: Potentials and bottlenecks at the landscape level in a Mediterranean case study. J. Clean Prod. 2020, $275,124043$. [CrossRef]

151. Menrad, K. Future impacts of biotechnology an agriculture and food processing. Outlook Agric. 1999, 28, 155-161. [CrossRef]

152. Mozas Moral, A.; Bernal Jurado, E.; Fernandez Ucles, D.; Medina Viruel, M.J.; Puentes Poyatos, R. Second degree cooperativism and ICT adoption. CIRIEC 2020, 100, 67-85. [CrossRef]

153. Mlambo, V.; Makkar, H.P.S. Calibration and validation of the C-14-labelled polyethylene glycol-binding assay for tannins in tropical browse. Anim. Feed Sci. Technol. 2005, 122, 29-40. [CrossRef]

154. Ugolini, F.; Mariotti, B.; Maltoni, A.; Tani, A.; Salbitano, F.; Garcia Izquierdo, C.; Macci, C.; Masciandaro, G.; Tognetti, R. A tree from waste: Decontaminated dredged sediments for growing forest tree seedlings. J. Environ. Manag. 2018, 211, $269-277$. [CrossRef] [PubMed]

155. Perez Neira, D.; Soler Montiel, M.; Delgado Cabeza, M.; Reigada, A. Energy use and carbon footprint of the tomato production in heated multi-tunnel greenhouses in Almeria within an exporting agri-food system context. Sci. Total Environ. 2018, 628-629, $1627-1636$. [CrossRef] [PubMed]

156. Cantarelli, F. The challenges for a sustainable agro food system development in Italy and even beyond. Econ. Agro Aliment. 2016, 18, 229-238. [CrossRef] 
157. D'Amato, S.; Serio, A.; Lopez, C.C.; Paparella, A. Hydrosols: Biological activity and potential as antimicrobials for food applications. Food Control 2018, 86, 126-137. [CrossRef]

158. De Nino, A.; Di Donna, L.; Maiuolo, L.; Mazzotti, F.; Napoli, A.; Perri, E.; Tagarelli, A.; Sindona, G. Hot chili pepper and virgin olive oil: Two functional foods of the Calabrian diet. A high tech approach for the evaluation of their quality and safety. J. Appl. Cosmetol. 2006, 24, 7-16.

159. Cheriet, F.; Tozanli, S. Attempt of construction of an industrial FDI attractiveness score: The case of agri-food industries in southern and eastern Mediterranean Countries. New Medit. 2008, 7, 5-16.

160. Cheriet, F. What differences in perceptions of local enterprises and multinational firms of their unstable strategic alliances relationships ? Rev. Int. PME 2016, 29, 95-118. [CrossRef]

161. Lezoche, M.; Hernandez, J.E.; del Alemany Díaz, M.M.E.; Panetto, H.; Kacprzyk, J. Agri-food 4.0: A survey of the supply chains and technologies for the future agriculture. Comput. Ind. 2020, 117, 103187. [CrossRef] 